\title{
2nd International Congress of
}

\section{Person Centered Medicine}

"Advancing Humanistic and Interdisciplinary Health Care"

Buenos Aires, Hotel Colón, November, 7-9 , 2014

www.icpcmbuenosaires2014.com

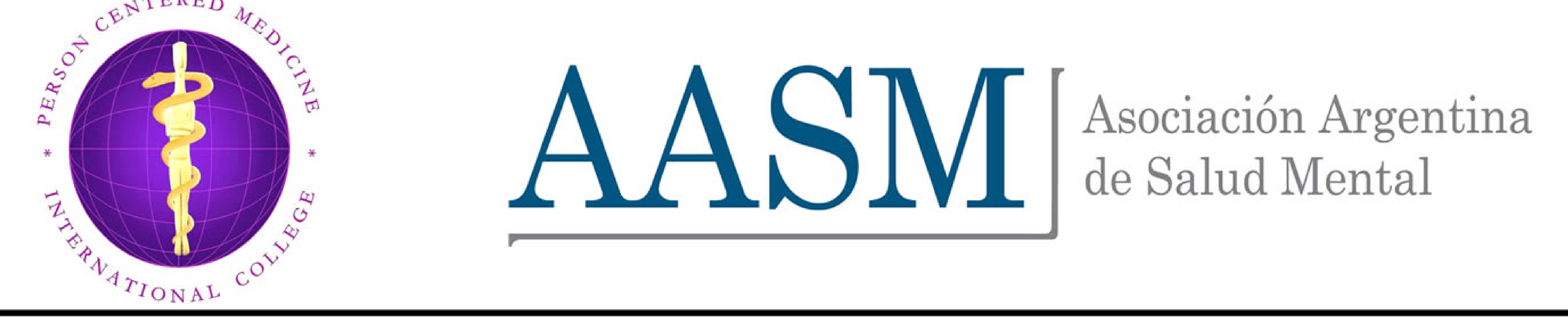

